\title{
PENGELOLAAN DAMPAK PEMBANGUNAN RUMAH POTONG HEWAN RUMINANSIA DI KOTA BATU
}

\author{
A. Tutut Subadyo \\ Jurusan Arsitektur Fakultas Teknik Universitas Merdeka Malang \\ e-mail : tutut.subadyo@unmer.ac.id
}

\begin{abstract}
ABSTRAK
Rumah Potong Hewan Rumnansia (RPH-R) adalah suatu kompleks bangunan dengan desain dan syarat tertentu sebagai tempat penyembelihan hewan untuk menghasilkan daging yang terdiri atas pemeriksaan ante-mortem, penyembelihan, penyelesaian penyembelihan dan pemeriksaan post-mortem. Kegiatan tersebut menimbulkan dampak negatif penting yang harus dikelola.Pengelolaan lingkungan guna menantisipasi terjadinya pencemaran dari RPH-R Kota Batu ditekankan pada kesehatan masyarakat. Pecemaran yang dominan adalah limbah cair (darah dan air), selain limbah padat (rumen, pakan ternak dan kotoran ternak) dan cemaran udara (bau dan debu). Pengelolaan limbah cair menggunakan instalasi pengolah air limbah (IPAL) dengan sistem biofilter anaerob-aerob. Proses biometanisasi bahan padat (campuran isi rumen, kotoran sapi, sisa pakan, dan urine) menjadi alternatif pengelolaan yang lain. Pengendalian pembentukan padatan terapung dan jaminan keselamatan dengan sistem aerobik. Proses anaerobik pretreatment direkomendasikan untuk mengurangi luaran cemaran udara (bau busuk dari limbah terbuka dan pengomposan). Langkah pengelolaan dampak lingkungan terhadap kesehatan masyarakat antara lain: (a) menata halaman depan sebagai ruang terbuka hijau / taman; (b) menanam vegetasi di dalam tapak; (c) melakukan penyiraman halaman; (d) membersihkan lantai dan perkakas setiap hari; (e) memasang exhaust fan pada unit-unit yang membutuhkan pengaturan kestabilan kualitas udara; (f) mengoperasikan sistem ventilasi silang; dan (g) menjaga penyinaran matahari yang cukup baik.
\end{abstract}

Kata kunci : dampak,limbah, lingkungan, rumah potong hewan

\section{PENDAHULUAN}

RPH-R merupakan unit pelayanan masyarakat dalam penyediaan daging yang aman, sehat, utuh, halal (ASUH) serta berfungsi sebagai sarana untuk melaksanakan : (1) penyembelihan hewan secara benar (sesuai dengan persyaratan kesehatan masyarakat veteriner, kesejahteraan hewan dan syariah agama); (2) tempat melaksanakan pemeriksaan hewan sebelum dipotong (ante-mortem inspection), pemeriksaan karkas dan jeroan (postmortem inspection) untuk mencegah penularan penyakit zoonosa ke manusia; dan (3) tempat pemantauan dan surveilans penyakit hewan dan zoonosis guna pencegahan, pengendalian, dan pemberantasan penyakit hewan menular.

Dalam rangka menciptakan RPH-R yang sehat dan bersih, perlu dilakukan upaya pengelolaan lingkungan. Dengan demikian harapan dari suatu kegiatan penyembelihan / penyembelihan hewan diminimalkan dampak negatifnya. Pembangunan RPH-R di Kota Batu menempati lahan seluas \pm 3.900 $\mathrm{m} 2$ dengan luas bangunan RPH yang direncanakan \pm $764 \mathrm{~m} 2$, ekstensi rencana Pasar Hewan seluas \pm 1.000 $\mathrm{m} 2$, halaman parkir dan areal ruang terbuka hijau \pm $2.000 \mathrm{~m} 2$ di atas tanah sertifikat hak milik Pemerintah Kota Batu. Tapak RPH-R di Kota Batu menempati lokasi yang sangat strategis, memiliki aksesibilitas mudah dijangkau dan berada di jalan raya Mojorejo Junrejo, dan bersebelahan dengan kandang ternak milik masyarakat serta berseberangan dengan fasilitas Krematorium Panca Budhi.
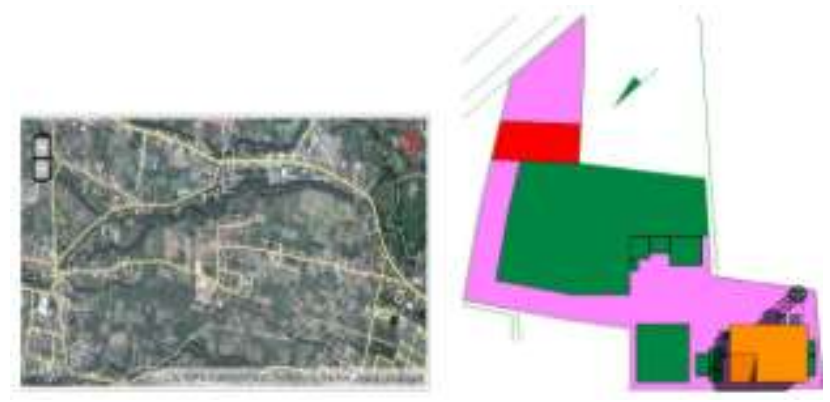

Gambar. 1. Lokasi dan Site Plan RPH-R di Kota Batu

Luas dan pemanfaatan lahan yang dipergunakan untuk tapak RPH-R Kota Batu dipandang cukup memadai apabila dikaitkan dengan ketentuan Koefisien Dasar Bangunan (Building Coverage) dimana luas tapak $3.900 \mathrm{~m} 2$ dengan luas bangunan $3.764 \mathrm{~m} 2$, luas lahan terbuka $2.000 \mathrm{~m} 2$. Site plan bangunan RPH-R Kota Batu terpola terbuka, dimana hubungan antar massa bangunan dihubungkan dengan selasar (gang way) dan dilengkapi dengan elemen vegetasi pada sisi luarnya. Lay out plan bangunan RPH-R Kota Batu disusun dengan konsep kemudahan pencapaian, kebersihan dan higienis, sirkulasi yang jelas dan kenyamanan pemakai, antisipasi bahaya kebakaran serta kenyamanan thermal dan sirkulasi udara serta manajemen sanitasi lingkungan yang optimal. 


\section{METODE}

Metode kegiatan dalam memprakiraan dampak lingkungan pembangunan RPH-R Kota Batu menggunakan metode rapid appraisal berbasis matriks interaksi Leopod. Metode ini mampu menggambarkan hubungan timbal balik di sekitar proyek, sebagai akibat kegiatan proyek terhadap komponen lingkungan. Kegunaan metode ini adalah untuk :

a. Menggambarkan hubungan sebab akibat (dampak negatif lingkungan) dari kegiatan proyek pembangunan RPH-R Kota Batu.

b. Mempermudah dalam melihat terjadinya dampak negatif lingkungan terhadap kesehatan masyarakat.

c. Melihat adanya dampak dari kegiatan proyek pembangunan RPH-R Kota Batu serta merencanakan pengelolaan dan pemantauan berdasarkan skala prioritasnya.

Forecasting dampak lingkungan dari RPH-R Kota Batu yang utama adalah limbah yang berasal dari kegiatan penyembelihan, pemindahan, pembersihan bulu, penjadian (rendening), pengaturan, pemrosesan dan pembersihan. Limbah RPH-R Kota Batu mempunyai sifat-sifat umum berupa darah, protein, lemak, kelarutan dan campuran zat organik tinggi, yang berasal dari kegiatan pengkandangan dan penyembelihan ternak. Dari pengkandangan ternak limbah cair berasal dari kegiatan pencucian atau sanitasi kandang, urine ternak dan air yang terkontaminasi limbah padat (sisa pakan dan kotoran ternak).

Bau yang tidak sedap yang berasal dari kotoran ternak merupakan media yang baik bagi perkembangan serangga (lalat dan nyamuk). Dari segi kesehatan lingkungan, lalat dan nyamuk merupakan vektor penyebar penyakit ke manusia. Dari kegiatan penyembelihan / penyembelihan ternak, limbah cair yang dihasilkan meliputi : darah dari penyembelihan, air limbah pencucian ruang penyembelihan, air limbah pencucian jeroan, dan cairan rumen.

Limbah RPH-R Kota Batu yang sangat potensial menyebabkan pencemaran adalah limbah cair. Berdasarkan karakteristiknya, limbah cair RPH$\mathrm{R}$ Kota Batu mengandung bahan organik, padatan tersuspensi, lemak, nitrogen dan fosfor. Pada RPH-R Kota Batu pengolahannya direncanakan menggunakan sistem biofiler. Sedangkan limbah padat seperti rumput sisa pakan, rambut/bulu ternak, kulit, tanduk, kuku, tulang, kotoran ternak dan isi rumen, yang penempatannya tidak ditimbun begitu saja sehingga menimbulkan masalah bau dan mengurangi nilai esteika suatu ruang dan lingkungan hidup.

\section{HASIL KEGIATAN}

Berdasarkan hasil analisis kegiatan dan kondisi rona lingkungan awal hasil observasi lapangan dan uji laboratorium, dapat diperkiraan dampak kegiatan RPH-R Kota Batu terhadap komponen lingkungan. Untuk memprediksi dampaknya, diperhatikan hal-hal spesifik terkait dengan daya dukung dan manajemen lingkungannya. Selain persyaratan teknis rancangan arsitektural bangunannya, kelengkapan dan keeratan hubungan dari fasilitas-fasilitas RPH-R, kaidah dan standar sanitasi (Standard Sanitation Operatioanl Procedure), sistem penyembelihan, Sistem Jaminan Halal (SJH) dan sistem keamanan daging yang akan dihasilkannya menjadi kriteria design fasilitas RPH$\mathrm{R}$ tersebut. Berikut disajikan gambar-gambar hasil preliminary design $\mathrm{RPH}-\mathrm{R}$ Kota Batu.
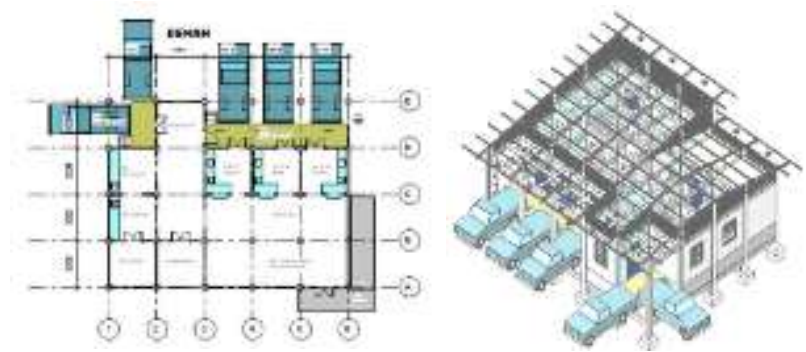

Gambar. 2. Denah dan Isometri Struktur Bangunan RPH-R Kota Batu
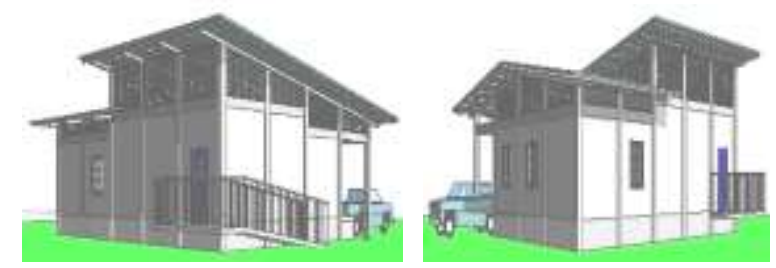

Gambar. 3. Sequence Bagian Belakang RPH-R Kota Batu
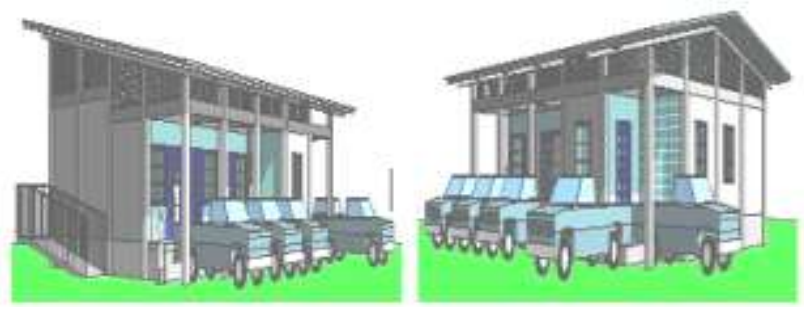

Gambar. 4. Sequence Bagian Depan RPH-R Kota Batu

Kegiatan operasional RPH-R Kota Batu akan berpengaruh terhadap komponen lingkungan (biofisik dan kesehatan masyarakat) sehingga perlu 
dilakukan upaya pengelolaan dan pengendalian dampak terhadap komponen lingkungan dan masyarakat sekitar. Pada tahap prakonstruksi pengelolaan lingkungan ditekankan melalui pendekatan teknis dan intitusi maupun sosial, agar tidak terjadi gejolak sosial akibat dari rencana kegiatan pembangunan, dengan melalui beberapa tahap: (a) sosialisasi rencana status dari RPH-R Kota Batu dengan meminta persetujuan masyarakat sekitar ; dan (b) pengajuan ijin untuk mendirikan RPH-R Kota Batu ke istansi yang berwenang.

Pada tahap prakonstruksi yang dikelola adalah lingkungan sosialnya, bila ada masyarakat sekitar yang kurang bisa menerima rencana pembangunan RPH-R Kota Batu. Melalui pendekatan teknis dan institusi guna masyarakat yang merasa kurang berkenan dengan rencana pembangunan tersebut diyakinkan. Pada tahap konstruksi kegiatan pengelolaan lingkungan ditekankan padakontrol/pemantauan kualitas fisika,kimia,dan biologi, mulai dari pematangan lahan sampai dengan kegiatan konstruksi.

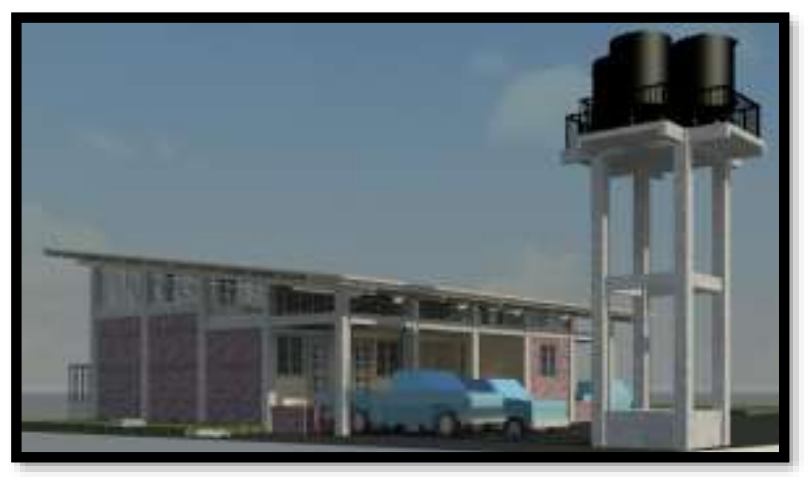

Gambar.5. Perspektif bangunan RPH-R Kota Batu

Pada tahap konstruksi, komponen lingkungan yang terkena dampak adalah kualitas lingkungan fisika, kimia, dan biologi. Untuk mengantisipasi terjadinya pencemaran kualitas udara, bau, bising dan air dilakukan pengukuran dan pengamatan dilapangan. Sedangkan untuk mengantisipasi terjadinya limpasan air hujan dibuat saluran drainase dan untuk lahan galian dimanfaatkan untuk pengurukan pada tapak yang dipandang kurang tinggi dari titik nol dari permukaan jalan.

\subsection{Pengelolaan Air Limbah}

Secara umum dapat diprediksi bahwa limbah cair yang dihasilkan dari RPH-R Kota Batu terdiri dari air pembersih ruang penyembelihan, air pembersih intenstinal, dan pembersihan kandang ternak. Untuk memantau jumlah limbah cair spesifik dan beban pencemarannya maka pemakaian air pembersih menggunakan sistem keran pengatur, sehingga aliran air dapat dikendalikan.

Beban padatan dan padatan tersuspensi pada limbah cair RPH-R Kota Batu bentukan partikel padat isi rumen dan isi intestinal mempunyai kemampuan degradasi rendah. Beban pencemaran terbesar RPHR Kota Batu berupa ceceran darah mulai dari ruang penyembelihan sampai ruang penggantungan. Darah mengakibatkan tingginya nilai $\mathrm{BOD}$ dan padatan tersuspensi. Pemanfaatan kembali darah hewan (untuk campuran pakan ternak, karena mengandung protein yang cukup tinggi) dengan cara menampungnya merupakan aspek penting yang disarankan pengendalian pencemarannya, sehingga nilai BOD air limbahnya menurun.
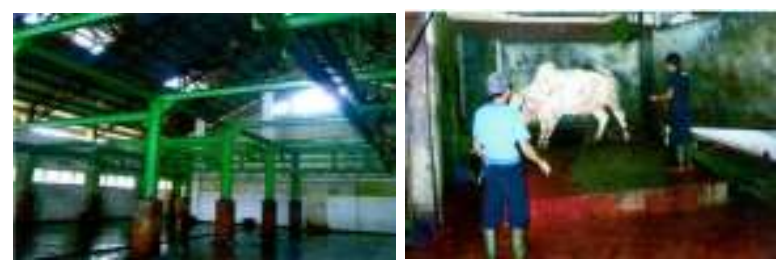

Gambar 6. Ilustrasi bangunan utama dan tempat penyembelihan ternak di RPH-R

Pengelolaan limbah cair di RPH-R Kota Batu direncanakan menggunakan IPAL dengan sistem biofilter anaerob-aerob. Proses pengolahannya dialirkan melalui saluran pembuang dan dilewatkan melalui saringan kasar (bar screen) untuk menyaring sampah yang berukuran besar. Setelah melalui screen air limbah dialirkan ke bak pemisah lemak atau minyak. Bak pemisah lemak tersebut berfungsi untuk memisahkan lemak atau minyak yang berasal dari kegiatan penyembelihan hewan, serta untuk mengendapkan kotoran pasir, tanah atau senyawa padatan yang tak dapat terurai secara biologis. Selanjutnya limpasan dari bak pemisah lemak dialirkan ke bak ekualisasi yang berfungsi sebagai bak penampung limbah dan bak kontrol aliran. Air limbah di dalam bak ekualisasi selanjutnya dipompa ke unit IPAL.

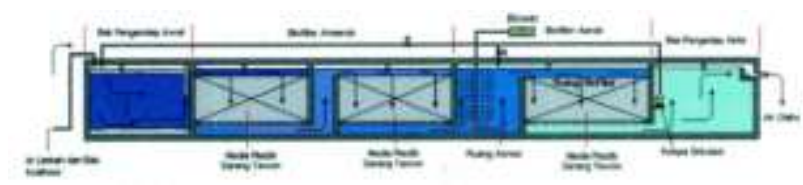

Gambar. 7. Proses Pengolahan Air Limbah RPH-R Kota Batu dengan proses biofilter anaerob-aerob.

Di dalam unit IPAL tersebut, air limbah dialirkan masuk ke bak pengendap awal, untuk mengendapkan partikel lumpur, pasir dan kotoran organik tersuspensi. Selain sebagai bak pengendapan, juga berfungsi sebagai bak pengurai senyawa organik 
berbentuk padatan, sludge digestion (pengurai lumpur) dan penampung lumpur. Air limpasan dari bak pengendap awal selanjutnya dialirkan ke bak anaerob dengan arah aliran dari atas ke bawah, dan dari bawah ke atas.
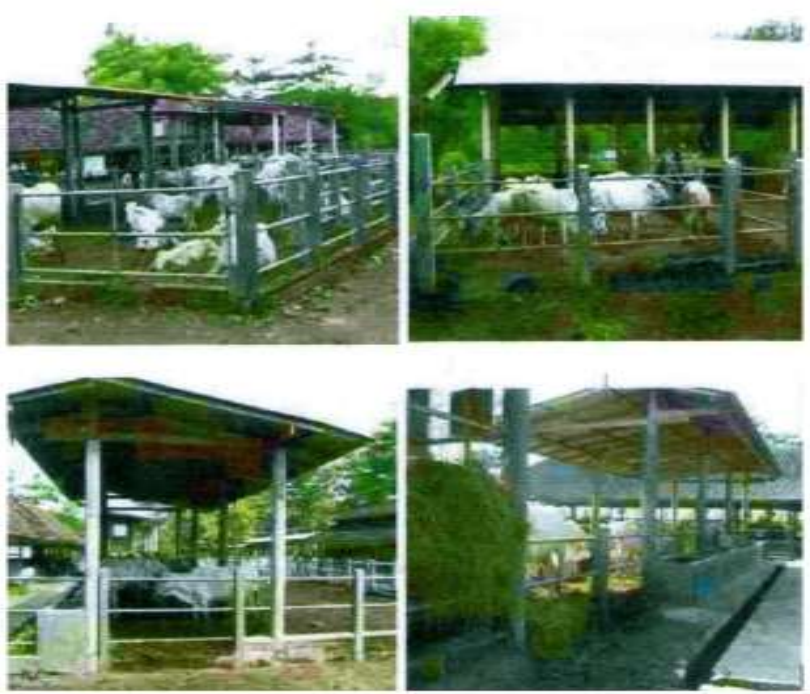

Gambar. 8. Ilustrasi kandang dan rak penyimpanan pakan pada komplek RPH-R, yang dapat menimbulkan bau tidak sedap.

Di dalam bak anaerob tersebut diisi dengan media dari bahan plastik tipe sarang tawon. Jumlah bak kontraktor anaerob terdiri dari dua buah ruangan. Penguraian zat-zat organik yang ada di dalam air limbah dilakukan oleh bakteri anaerobik atau facultatif aerobik. Setelah beberapa hari operasi, pada permukaan media filter akan tumbuh lapisan film mikro-organisme. Mikro-organisme inilah yang akan menguraikan zat organik yang belum sempat terurai pada bak pengendap.

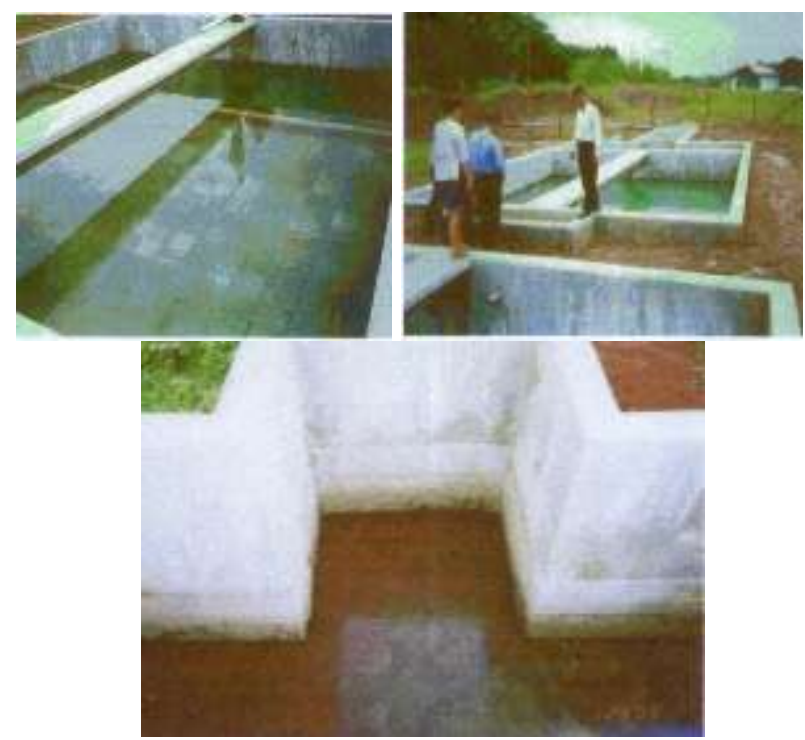

Gambar 9. Contoh konstruksi media biofilter, IPAL sistem biofilter, dan bak pemisah lemak.
Air limpasan dari bak anaerob dialirkan ke bak aerob. Di dalam bak aerob, sambil diaerasi atau dihembus dengan udara sehingga mikro-organisme yang akan menguraikan zat organik yang ada dalam air limbah serta tumbuh dan menempel pada permukaan media. Dengan demikian air limbah akan kontak dengan mikro-organisme yang tersuspensi dalam air maupun yang menempel pada permukaan media yang mana hal tersebut dapat meningkatkan efisiensi penguraian zat organik, deterjen, serta mempercepat proses nitrifikasi, sehingga efisiensi penghilangan ammonia menjadi lebih besar. Proses ini sering dinamakan aerasi kontak (contact aeration).

Dari bak aerasi, air dialirkan ke bak pengendap akhir. Di dalam bak ini lumpur aktif yang mengandung massa mikro-organisme diendapkan dan dipompa kembali ke bagian inlet bak aerasi dengan pompa sirkulasi lumpur. Sedangkan air limpasan (over flow) dialirkan ke bak khlorinasi. Di dalam bak khlor ini air limbah dikontakkan dengan senyawa khlor untuk membunuh mikroorganisme patogen. Air olahan yang keluar setelah proses khlorinasi dapat langsung dibuang ke badan air (sungai) atau saluran umum.

\subsection{Pengelolaan Limbah Padat}

Rumen hewan ruminansia (sapi, kerbau, kambing dan domba) mengandung bahan-bahan yang tidak dapat dicerna. Cara pemisahan dan pembuangan isi rumen akan mempengaruhi beban limbah dari RPH$\mathrm{R}$ Kota Batu. Isi rumen hendaknya dibuka ditempat khusus kemudian ditembakkan ke penampungan isi rumen dengan 'blow-gun, sehingga ceceran isi rumen bisa diminimalisasikan, sedangkan isi intestine dan intestinal mucus dapat disalurkan ke saluran air limbah. Pengeluaran isi rumen akan menaikkan buangan padat yang dihasilkan. Oleh karenanya rumen yang tidak terolah dikategorikan sebagai bahan yang mengandung epidemiologis.

Sementara bau tidak sedap yang berasal dari kotoran hewan (dari kandang maupun dari ruang penyembelihan serta pasar hewan) jika tidak dikelola akan menjadi media perkembangan lalat dan nyamuk. Dari segi kesehatan lingkungan, nyamuk dan lalat merupakan vector perantara penyebaran penyakit ke manusia. Oleh karena itu bau tidak sedap ini merupakan aspek penting yang perlu diperhatikan di RPH-R Kota Batu karena dapat menyebabkan terganggunya kualitas udara di sekitar tapak. 


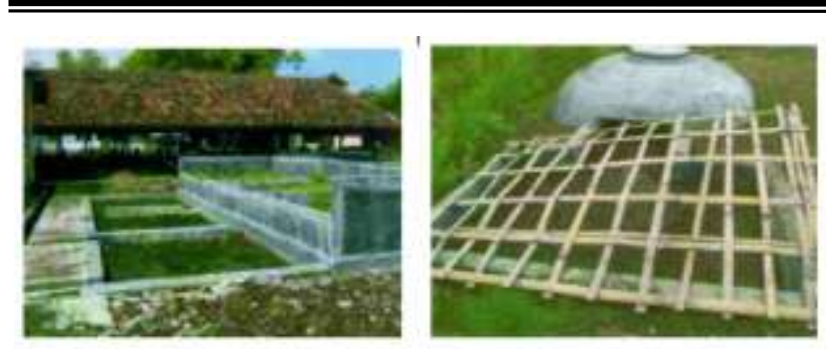

Gambar.10. Ilustrasi tempat pengumpulan , penyaringan kotoran hewan dari RPH-R dan pemanfaatannya sebagai biogas.

Pemindahan limbah padat dari proses penyembelihan / penyembelihan dan kandang ternak merupakan hal yang harus dikelola. Dalam pengelolaan limbah padat pada RPH-R Kota Batu direkomendasikan untuk diproses dengan dehidrasi. Salah satu konsekuensi dari regulasi pengadaan daging yang berkategori ASUH adalah tidak diijinkan untuk membuang limbah sejenis ini di dekat lokasi di RPH-R Kota Batu.

Proses biometanisasi bahan padat (campuran isi rumen, kotoran sapi, sisa pakan, dan urine) di RPH-R Kota Batu menjadi alternatif pengelolaan yang lain. Pengendalian pembentukan padatan terapung dan jaminan keselamatan pengolahan bahan berkaitan dengan adanya material-material asing yang terikut dalam isi rumen.

Keuntungan yang didapat dari pengolahan limbah padat dengan sistem aerobik adalah pengurangan massa dan volume yang telah berubah menjadi energi biogas. Selain itu proses anaerobik pretreatment yang direkomendasikan pada RPH-R Kota Batu dapat mengurangi keluaran pada penangkapan dan pengolahan cemaran udara untuk menghilangkan bau busuk dari penanganan limbah terbuka dan pengomposan. Guna mendapatkan dekontaminasi yang sempurna selama pengomposan, direkomendasikan untuk menggunakan mesin pembalik intensif dan dilakukan paling tidak dua kali seminggu. Proses pengomposan memiliki peran besar dalam pengolahan dan pemrosesan limbah padat pada RPH-R Kota Batu. Jumlah dan struktur serat yang diberikan dalam campuran, pengomposan dapat menjadi metoda untuk mengolah isi rumen, sisa pakan, kotoran sapi/kerbau, lemak dan bahan-bahan tersaring lainnya.

\subsection{Pengelolaan Limbah Udara dan Kontaminasi Silang}

Letak tapak RPH-R Kota Batu di jalan raya Mojorejo - Junrejo dan berhadapan dengan Krematorium Kota Batu, mempunyai potensi cemaran debu masuk ke dalam tapak dan bangunan RPH. Untuk mengatasi hal tersebut, beberapa langkah pengelolaan yang bisa dilakukan antara lain: (a) menata ruang halaman depan sebagai ruang terbuka hijau yang dikelola sebagai taman; (b) menanam pohon-pohon dan perdu, serta menempatkan pot-pot ukuran besar di halaman RPHR; (c) melakukan penyiraman pada halaman depan ; (d) membersihkan debu lantai dan perkakas setiap hari; (e) memasang exhaust fan pada unit-unit yang membutuhkan pengaturan kestabilan kualitas udara; (f) mengoperasikan sistem ventilasi silang yang baik; dan (g) menjaga penyinaran matahari yang cukup baik.

Sementara itu, untuk mengatasi kebisingan diletakkan barier kebisingan berupa tanaman pada area perawatan atau ruang yang membutuhkan ketenangan, dengan : (a) melarang kendaraan yang parkir di sekitar tapak RPH-R Kota Batu membunyikan klakson atau bel; dan (b) melapisi dinding beberapa ruang perawatan dengan bahan yang dapat mereduksi suara (kedap suara).

Dalam rangka pencegahan terjadinya kontaminasi silang di RPH-R Kota Batu dilakukan upaya-upaya sebagai berikut: (a) evaluasi berkala kegiatan surveilans terhadap penyakit infeksi dan menyusun kebijakan program pengendalian terjadinya kontaminasi silang dan infeksi serta membuat laporan bulanan; (b) adanya komite kontrol dan pengelola program pengendalian kontaminasi silang dan infeksi yang dilaksanakan secara konsisten; (c) pengawasan berkala baik secara aktif maupun pasif sehingga kejadian kontaminasi silang dan infeksi dapat ditemukan sedini mungkin; dan (d) petugas RPH-R Kota Batu selalu mencuci tangan sebelum dan sesudah masuk ruangan dengan sabun antiseptik, melakukan hygine perorangan dan melakukan teknik aseptik sesuai prosedur tetap yang telah ditetapkan.

\section{KESIMPULAN}

- Design bangunan RPH-R Kota Batu yang taat azas dan mengacu pada kaidah arsitektur yang sustainibel menjadi kunci awal pengelolaan dampak lingkungan terhadap masyarakat di sekitar tapak.

- Dampak dari kegitan pembangunan dan operasionalisasi RPH-R Kota Batu dapat diminimalisir dengan penerapan Standart Sanitation Operation Procedure (SSOP), Good Slaughtening Practice (GSP), dan Sistem Jaminan Halal (SJH). 


\section{REFERENSI}

Apriyantono, A. et al. 2007. Pedoman Produksi Pangan Halal. Khairul Bayan Press. Jakarta.

Badan Standarisasi Nasional (BSN). 1999. Standart Nasional Indonesia (SNI) Nomor 01.6159-1999 tentang Rumah Potong Hewan (RPH). Jakarta.

Badan Standarisasi Nasional (BSN). 2008. Standart Nasional Indonesia (SNI) Nomor. 3932:2008. Tentang Mutu Karkas dan Daging Sapi. Jakarta.

Badan Karantina Pertanian Republik Indonesia. 2010. Pedoman Pengawasan Kehalalan Karkas, Daging dan Jeroan dari Luar Negeri. Jakarta.
Darmono. 2008. Lingkungan Hidup dan Pencemaran Hubungannya dengan Toksikologi Senyawa Logam. UI Press. Jakarta.

Departemen Pertanian Republik Indonesia. 2010. Pedoman Teknis Penataan Rumah Potong Hewan (RPH). Direktorat Kesmavet. Dirjen Peternakan. Jakarta.

LPPOM MUI. 2011. Pedoman Pengelolaan Rumah Potong Hewan Halal (RPH-H). MUI. Jakarta.

Peraturan Menteri Pertanian 2010 tentang Persyaratan Rumah Potong Hewan Ruminansia (RPH - R) dan Unit Penanganan Daging (Meat Cutting Plant). Kementerian Pertanian Republik Indonesia. Jakarta.

Neufert Architect Data. 2010. 